Somnath Saha, MS

Sharmila Sen, $\mathrm{MD}^{2}$

V. Padmini Saha, $\mathrm{MCh}^{3}$

Sudipta Pal, MS'

${ }^{1}$ Department of ENT \& HNS

R.G. Kar Medical College \& Hospital

Kolkata, West Bengal, India

2Department of Pathology

Calcutta National Medical College

Kolkata, West Bengal, India

${ }^{3}$ Department of Plastic \& Reconstructive Surgery

RG Kar Medical College \& Hospital

Kolkata, West Bengal, India
Correspondence: Dr Sudipta Pal

223, Lane No.-3, Jhilpark

J.C.Khan Road, P.O.: Mankundu

Dist: Hooghly, West Bengal

India

PIN: 712139

Phone: +919051757391/+919231535309

E-mail:drsudiptapal@gmail.com

Reprints will not be available from the authors.

The authors declared that this represents original material that is not being considered for publication or has not been published or accepted for publication elsewhere, in full or in part, in print or electronic media; that the manuscript has been read and approved by all the authors, that the requirements for authorship have been met by each author, and that each author believes that the manuscript represents honest work.

Disclosures: The authors signed disclosures that there are no financial or other (including personal) relationships, intellectual passion, political or religious beliefs, and institutional affiliations that might lead to a conflict of interest.

\title{
Giant Cell Tumor of the Maxilla
}

\begin{abstract}
Objective: To present a rare case of maxillary swelling; its investigation and management.
\end{abstract}

\section{Methods:}

\author{
Design: Case Report \\ Setting: Tertiary Government Teaching Hospital \\ Patient: One
}

Results: A 45-year-old female presented with a right maxillary swelling of six months duration. Radiological investigation revealed a radiolucent lesion arising from the inferior aspect of the right maxilla with no areas of calcification. Incisional biopsy report was consistent with giant cell tumor. The mass was excised via a Weber Ferguson incision under general anesthesia.

Conclusion: Though rare, giant cell tumor should be considered as one of the differential diagnosis in cases of maxillary swelling. Adequate surgical excision with long-term follow-up should be the treatment of choice for managing a giant cell lesion of the maxilla.

Keywords: maxillary swelling, giant cell tumor

Giant cell tumors make up 4-5\% of all primary bone tumors. ${ }^{1}$ They are usually benign, but occasionally, they can be primarily malignant or can undergo malignant transformation. They can behave aggressively and metastasize. More than $75 \%$ are located in the epiphyseal region of long bones, and the most common locations in order of frequency are the lower end of femur, upper end of tibia and lower end of radius.

True giant cell tumors (GCT) of the head and neck are exceedingly rare and constitute approximately $2 \%$ of all GCTs. ${ }^{2}$ Most of the lesions diagnosed as giant cell tumors are in truth giant cell granulomas. In one large series of GCT from South India, Rockwell \& Small reported only one case of maxillary involvement over a period of 10 years. ${ }^{3}$ We present a case of GCT involving the right maxilla from a rural Medical college of Bengal with its management. 


\section{CASE REPORT}

A 45-year-old woman presented to the Department of Otorhinolaryngology with a painless swelling on the right side of the face for six months. (Figure 1) The swelling was of insidious onset and had progressed slowly. There was no history of any loosening of teeth. There was a history of trauma to the face five to six years ago. There were no facial paraesthesias, nasal discharge, epiphora or systemic symptoms. Medical history and family history were non-contributory.

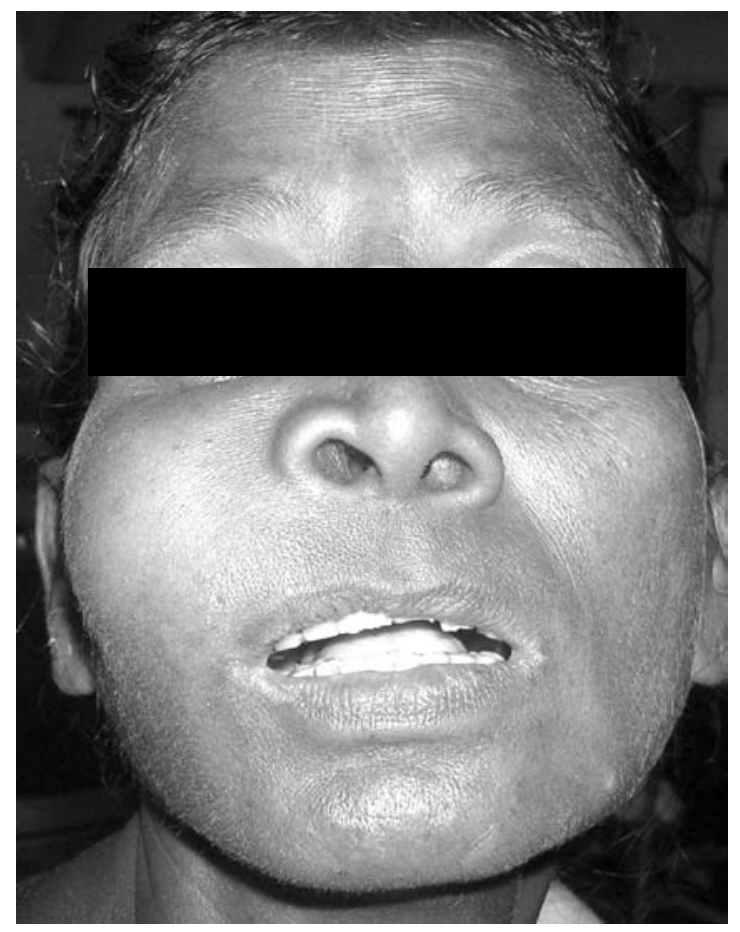

Figure 1. Clinical photograph of the patient showing right maxillary swelling

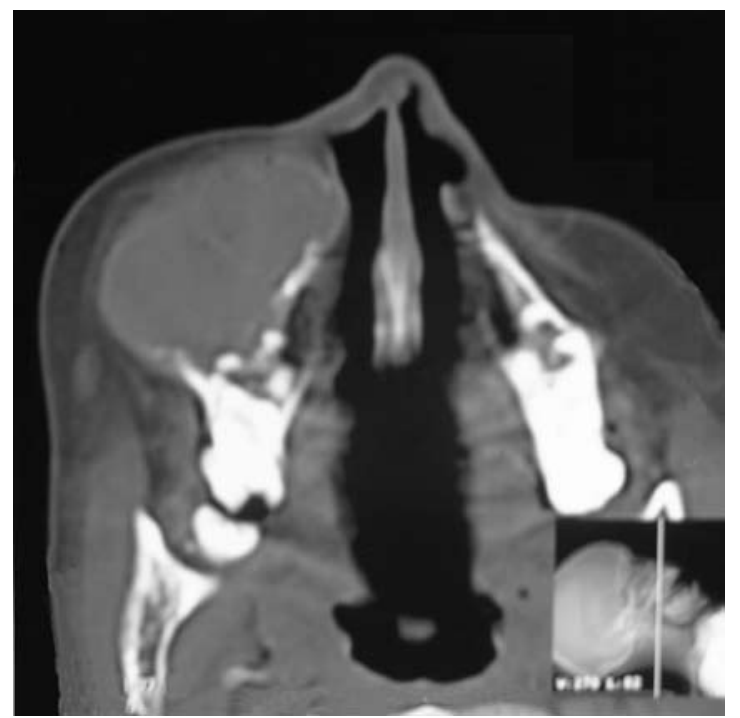

Figure 2. Axial CT scan of paranasal sinuses showing tumor in the right maxilla. Note the homogenous opacity without any calcification along with destruction of adjoining bone.

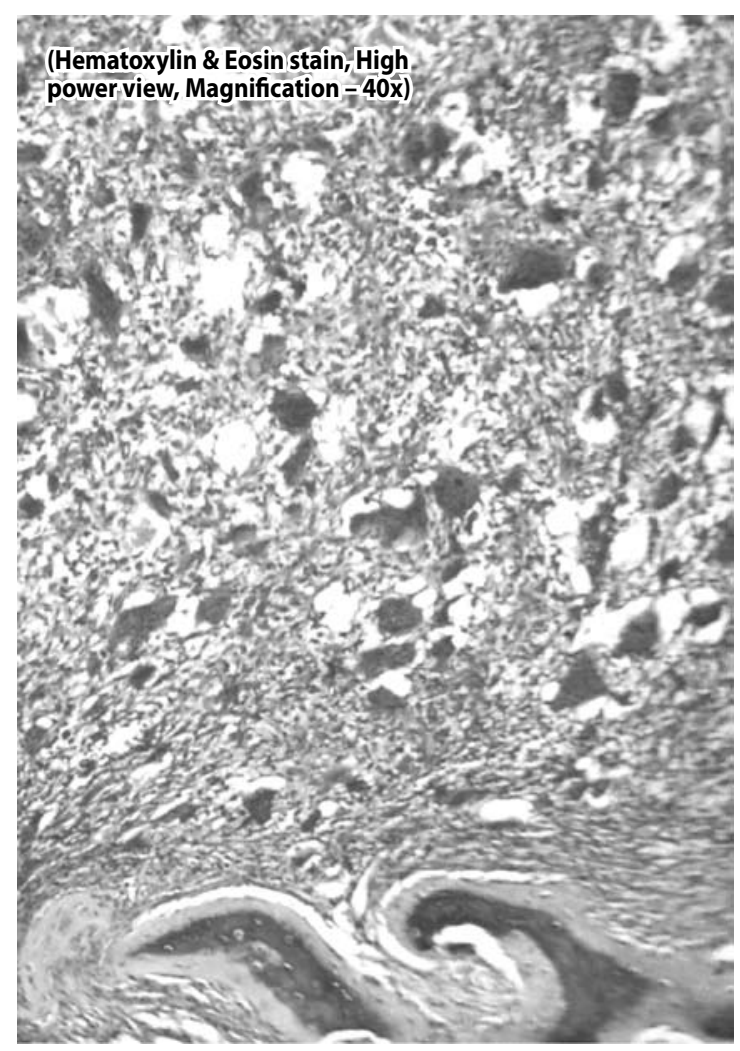

Figure 3. Microphotograph of the histopathological slide (Hematoxylin \& Eosin stain, High power view, Magnification - 40X) showing numerous multinucleated giant cells distributed in a highly cellular stroma composed of spindle-shaped and round cells.

The patient did report using tobacco.

Examination revealed a diffuse hard swelling on the right side of the face of approximately $5 \mathrm{~cm}$. diameter obliterating the ipsilateral nasolabial fold and pushing up the ala of nose. The swelling was nontender, hard, smooth-surfaced, firmly related to the underlying maxillary bone and had an eggshell-like crackling on palpation. The overlying skin was normal and there was no local rise of temperature. Intraoral examination revealed a swelling in the gingivo-labial groove extending from the right upper lateral incisor to the first molar with no extension to the palate. There was no associated lymphadenopathy.

Routine hemogram was within normal limits. Serum calcium was 9.3 $\mathrm{mg} / \mathrm{dl}$, phosphorus $4.1 \mathrm{mg} / \mathrm{dl}$ and alkaline phosphatase was $92 \mathrm{UL}$. ECG and Chest $\mathrm{X}$-ray were within normal limits. Computed tomography scan showed a radiolucent lesion arising from the inferior aspect of the right maxilla with no areas of calcification, completely obliterating the left maxillary antrum with thinning and destruction of parts of the antral wall. (Figure 2) It extended inferiorly into the body of the maxilla up to the alveolus, involving the adjoining teeth. Infero-medially, it reached the midline. Medially, it almost obliterated the posterior third of the left nasal cavity. Posteriorly it reached the pterygoid plates. Superiorly, it 


\section{CASE REPORTS}

extended up to the floor of the orbit.

Incisional biopsy through the involved gingivo-labial sulcus yielded a histopathological reading of numerous multinucleated giant cells, which were distributed in a highly cellular stroma composed of spindleshaped and round cells which were found mostly in the areas of hemorrhages. The giant cells were numerous and distributed randomly, their nuclei mainly confined to the center of the cells leaving a clear zone of cytoplasm at the periphery. Ingested RBCs and scanty collagen were also seen. (Figure 3 ) These findings were consistent with diagnosis of a giant cell tumor.

Under general anesthesia, the tumor was exposed by a WeberFerguson incision and a $5 \mathrm{~cm} \times 5 \mathrm{~cm}$ mass was enucleated. Postoperative recovery was uneventful and the final histopathological report was consistent with giant cell tumor.

\section{DISCUSSION}

Multinucleated giant cells are found in many fibro-osseous lesions of the jaw with many differential diagnoses. The giant cells in themselves are of little diagnostic importance and may be found in a number of pathologies affecting the jaw. ${ }^{4}$ Giant cell tumors (GCTs or osteoclastomas) are epiphyseal mesenchymal neoplasms of low malignant potential, comprising $4-5 \%$ of all primary bone tumors in adults. ${ }^{1}$ True GCTs constitute $2 \%$ of all giant cell-rich tumors of the jaw. ${ }^{2}$ They usually occur after the second decade of life. Growth of the tumor is intermittent and variable, and pain is the commonest presenting symptom. ${ }^{4}$ GCT may sometimes be associated with other pathologies like Von Recklinghausen's disease, Francescatti syndrome, hyperthyroidism and Paget's disease., Multiple GCTs, although rare, do occur and may be associated with Paget's disease. Malignant GCT accounts for $5 \%-10 \%$ of all GCTs and is usually secondary to previous irradiation of benign $\mathrm{GCT}^{7}$ although a minor proportion of malignant GCTs occur de novo. In GCT, the multinucleated giant cells do not appear to be neoplastic and result from fusion of circulating monocytes recruited into the lesion. The mononuclear stromal cells form the neoplastic component as it is the only proliferating element in the lesion. Their nature is controversial. They are clearly mesenchymal in origin rather than hematopoietic and share many features with normal mesenchymal stromal cells.

Giant-cell tumor of the jaw is a difficult clinical diagnosis as it may resemble other jaw lesions. The differentiation between these entities may be impossible even on biopsy without radiographic and clinical correlation. ${ }^{2}$ Radiologically, GCT is characterized by a lytic, expansile lesion in the epiphysis usually without peripheral bone sclerosis or periosteal reaction. The lesion is usually multilocular and may show multiple fluid levels or soft tissue density mass with expansion of the bone. Cystic (secondary aneurysmal bone cyst) components are reported in $14 \%$ of GCTs. The bony cortex is usually intact. The post contrast scan reveals homogenous enhancement of the mass. On MRI, the solid components demonstrate low to intermediate signal intensity in a T2 weighted image, a feature that can be helpful in diagnosis.?

True GCTs of the jaw should be clinically, radiologically and histologically differentiated from a giant cell reparative granuloma, brown tumor of hyperparathyroidism, aneurysmal bone cysts and cherubism.

Giant cell reparative granuloma (GCRG) of the jaw may be either peripheral-involving the gingiva and the alveolar mucosa or central - occurring as an endosteal lesion within the jaw bones. ${ }^{4}$ These lesions are related to prior tooth extraction or an ill-fitting denture and are self limited, may regress, seldom recur \& never metastasize. Histopathologically, its hemorrhagic fibroblastic background with innumerable giant cells differentiates it from a GCT.' Analyzing four cases of giant cell lesion of the maxilla, Stolovitzky et al. hypothesize that giant cell "granuloma" of the maxilla and paranasal sinuses and true GCTs of these bones represent a continuum of a single disease process, which may have an aggressive clinical behavior. ${ }^{8}$

In hyperparathyroidism, the mandible or maxilla may be the site for a giant cell lesion (Brown Tumor). Hyperparathyroidism should always be considered if the patient is older, if the maxilla or facial bones or both are the sites if involvement and recurrences prevail. ${ }^{4}$ Differential diagnosis of brown tumors of hyperparathyroidism from other jaw tumors is based mainly on clinical and laboratory data such as serum and urinary levels of calcium, phosphates, radioimmunoassay for parathyroid hormone, phosphate clearance, bone and serum alkaline phosphatase, etc. ${ }^{9}$

Aneurysmal bone cysts rarely occur in the maxilla, orbit, ethmoid or frontal bones. These lesions are slow growing and predominantly affect patients below the age of 20 years. The lesions are multilocular and demonstrate multiple fluid levels. Microscopically, they consist of numerous blood filled cavernous spaces lined by young connective tissue but devoid of endothelial lining, elastic or muscular elements.

Cherubism is an autosomal dominant disorder affecting the maxilla and mandible, where osteoclastic and osteoblastic activity of the bones cause them to be replaced by fibrous tissue along with cysts. Cherubism is a rare differential for GCT of jaw bones..$^{10}$

A main microscopic difference between a true giant cell tumor and these close morphologic mimics is based on the spatial relationship 
between giant and stromal cells in the lesion. In GCT, giant cells tend to be distributed regularly and uniformly whereas in lesions that simulate giant cell tumor, foci containing numerous clumped giant cells alternate with large areas devoid of giant cells.

Treatment of GCT usually consists of surgical resection and the type of surgery depends on location of the tumor. The recommended surgical procedure in GCTs is curettage with bone grafting or en bloc excision with replacement with allograft or biocompatible material. In one advanced central giant cell lesion of the maxilla, Marrioni et al. described maxillectomy as the treatment of choice and they successfully reconstructed the maxillary defect with autologous calvaria and a temporalis muscle pedicled flap. ${ }^{2}$ In the present case, partial anterolateral maxillectomy was done and the defect was covered only by soft tissue from the cheek.

Recurrence is common and the type of initial surgical removal is the most significant factor in recurrence. Recurrence usually occurs if curettage or any other treatment short of complete removal is employed. The recurrence rate is $34 \%$ following curettage and $7 \%$ following wide resection. ${ }^{10}$

Though rare, giant cell tumor should be considered as one of the differential diagnosis in cases of maxillary swelling. The diagnosis is made on the basis of radiological and histological features. Adequate surgical excision with long-term follow-up should be the treatment of choice for managing a giant cell lesion of the maxilla.

REFERENCES

1. Som PM, Brandwein M. Sinonasal cavities: inflammatory diseases, tumors, fractures and postoperative findings. In: Som PM, Curtin HD editors. Head and Neck Imaging Vol. 1, 3rd ed. New York: CV Mosby Year Book Publishers; 1996. pp. 126-318.

2. Marioni G, Marchese-Ragona R, Guarda-Nardini L, Stramare R, Tognazza E, Marino F, Staffieri A. Giant cell tumour (central giant cell lesion) of the maxilla. Acta Otolaryngol. $2006 \mathrm{Jul} ; 126(7): 779$ 81.

3. Rockwell MA, Small CS. Giant-cell tumors of bone in South India. J Bone Joint Surg Am. 1961 Oct; 43-A:1035-1040.

4. Stacy GS, Peabody TD, Dixon LB. Mimics on radiography of giant cell tumor of bone. AJR Am J Roentgenol. 2003 Dec;181(6):1583-1589.

5. Micheau C, Schwaab G, Vera Sempere FJ, Llombart-Bosch A. Giant cell tumors of maxilla; Ann Otolaryngol Chir Cervicofac.1987;104(4):251-7.

6. Mooney WW, Bridger GP, Baldwin M, Donellan M. Recurrent giant cell tumour of the maxilla associated with both Paget's disease and primary hyperparathyroidism. ANZ J Surg. 2003 Oct; 73(10):863-864.

7. Murphey MD, Nomikos GC, Flemming DJ, Gannon FH, Temple HT, Kransdorf MJ. From the archives of AFIP. Imaging of giant cell tumor and giant cell reparative granuloma of bone: radiologic-pathologic correlation. Radiographics, 2001 Sep-Oct; 21(5):1283-309.

8. Stolovitzky JP, Waldron CA, McConnel FM. Giant cell lesions of the maxilla and paranasal sinuses. Head Neck. 1994 Mar-Apr;16(2):143 - 148.

9. Magu S, Mathur SK, Gulati SP, Yadav A, Kaushal V.- Giant cell reparative granuloma of the base of the skull presenting as a parapharyngeal mass. Neurol India. 2003 Jun;51 ( 2):260-262.

10. McDonald DJ, Sim FH, McLeod RA, Dahlin DC. Giant-cell tumor of bone. J Bone Joint Surg Am 1986 Feb;68(2):235-242. 